\title{
Health Problems and Complementary Medicine in the First Trimester Pregnancy
}

\author{
Sibel Hakli (Corresponding author) \\ Istanbul Development University, Health Services Vocational School, Istanbul, Turkey \\ E-mail: shakli@gelisim.edu.tr \\ Dilara Dolgun Elmas \\ Koc University Hospital, Istanbul, Turkey \\ Nevriye Rustemoglu \\ Tekirdag Kapakli County State Hospital, Tekirdag, Turkey \\ Gulay Rathfisch \\ Istanbul University, Cerrahpasa Florence Nightingale School of Nursing, Istanbul, Turkey
}

\begin{abstract}
Gestation is a term which physiological, psychological and social changes are experienced in life and it is necessary to adapt to these changes. However, in every pregnancy, risky situations may occur which may have negative consequences for fetüs and mother. Among these risky cases, in the first trimester are spontaneous abortion, ectopic pregnancy, gestational trophoblastic disease, hyperemesis gravidarum. There were no studies on ectopic pregnancy and gestational trophoblastic disease when the literature was searched. It has been observed that most of your work was about nausea and vomiting seen in this period. However, it is observed that the results of these studies do not contain conclusive evidence. Bed rest, Chinese herbal medicines, acupuncture have been used in the prevention of miscarriages. In hyperemesis gravidarum, it has been observed that many complementary medical methods such as ginger, vitamin B1, vitamin B6, lemon oil inhalation, mint oil, chamomile, moxibustion, tactile massage, hypnosis, acupuncture, acupressure and social support are used. Many complementary methods are similar to nursing in that they centre on the concept of holism. Therefore, information on complementary therapies and their ares of use should be included in nursing curriculums, nurses should be updated on these therapies through in-service trainings.
\end{abstract}

Keyword: Complementary Medicine, First Trimester, Hyperemesis Gravidarum, Nursing.

DOI: $10.7176 / J S T R / 5-4-23$

\section{Birinci Trimester Gebeliklerde Yaşanan Sağlık Sorunları Ve Tamamlayıcı Tıp Buluşması}

\section{Özet}

Gebelik, yaşamda fizyolojik, psikolojik ve sosyal değişimlerin yaşandığı ve bu değişimlere uyum gerektiren bir dönemdir. Gebelikte fetüs ve anne olumsuz sonuçlar doğurabilecek riskli durumlar ortaya çıkabilir. Bu riskli durumlardan 1. Trimesterde spontan abortus, ektopik gebelik, gestasyonel trofoblastik hastalık(GDM), hiperemezis gravidarumdur. Literatür tarandığında ektopik gebelik ve gestasyonel trofoblastik hastalık adına çalışmalar bulunamamıştır. En çok çalışmanın bu dönemde görülen bulantı ve kusmayla ilgili yapılmış olduğu görülmüştür. Fakat bu çalışmaların sonuçlarının da kesin kanıtlar içermediği gözlenmiştir. Düşüğün önlenmesinde yatak istirahati, Çin bitkisel ilaçları, akupunktur gibi yöntemlerin kullanıldığı görülmüştür. Hiperemezis Gravidarumda ise zencefil, B1 vitamini, B6 vitamini, limon yağı inhalasyonu, nane yağı, papatya, ısı terapi, masaj terapi, hipnoz, akupunktur, akupressür ve 
sosyal destek olmak üzere birçok tamamlayııı tıp yöntemi kullanılmakta olduğu izlenmiştir. Tamamlayıcı tedavi metotlarının birçoğu holizm kavramına odaklanma açısından hemşirelikle benzer özellik taşımaktadır. Bu nedenlerle tamamlayıcı terapiler ve kullanımına ilişkin bilgiler hemşirelik müfredatına konmalı, hizmet içi eğitim programları kapsamında, tamamlayıcı terapiler konusunda hemşirelerin bilgi birikimleri güncellenmelidir.

\section{Anahtar Kelimeler: Tamamlayııı Tıp, Birinci Trimester, Hiperemezis Gravidarum, Hemşirelik}

\section{Giriş}

Gebelik, yeni bir canlının meydana gelmesinde kadın ve erkek üreme hücrelerinin birleşmesi sonucu başlayan ve doğumla sona eren bir olaydır. İnsanlarda ortalama gebelik süresi 40 hafta ya da 280 gündür (MEB, 2012). Dokuz aylık gebelik süresi üçer aylık periyotlara ayrılmakta, buna da trimester denmektedir. 1-12. hafta 1. trimester, 13-28. hafta 2. trimester ve 29-40. hafta 3. trimester olarak adlandırılmaktadır (Kızılkaya, 2017:348). Bu derleme, birinci trimester gebeliklerde yaşanan sağlık sorunlarında tamamlayıcı tıp uygulamalarının literatür doğrultusunda incelenmesi ve tamamlayıcı tıbbın hemşirelikteki yerinin irdelenmesi amacıyla yapılmıştır.

\section{Birinci Trimester Gebeliklerde Yaşanan Sağlık Sorunları}

Gebelik dönemi kadın yaşamında fizyolojik, psikolojik ve sosyal değişimlerin yaşandığı ve bu değişimlere uyum gerektiren önemli bir dönemdir. (Karataş ve Mete, 2012:47) Birçok insan gebeliği sağllklı yeni doğan dünyaya gelmesiyle olumlu sonuçlanan doğal bir olay olarak görür. Ancak her gebelikte fetüs, anne ya da her ikisi içinde olumsuz sonuçlar doğurabilecek riskli durumlar ortaya çıabilir. Bu riskli durumlardan 1. trimesterde görülenler spontan abortus, ektopik gebelik, gestasyonel trofoblastik hastalık(GDM), hiperemezis gravidarumdur (Kızılkaya, 2017:508).

Spontan abortusların \%80'i ilk üç ayda gerçekleşir. İlk 12 hafta içinde oluşan düşükler erken düşük, 1320. Haftalar arası oluşanlar da geç düşük adını alır. Gebeliklerin \%10’u ilk 12 haftada kendiliğinden sonlanmaktadır. İlk trimester düşüklerinin \%60’ı fetal genetik anomalilerden kaynaklanır, büyük çoğunluğu anne ile ilişkisizdir (Kızılkaya, 2017:509). Klinik seyrine göre abortuslar beş grupta incelenir; Abortus imminens (Düşük tehdidi), Abortus incipiens (Önlenemeyen düşük), Missed abortuslar, Habituel abortuslar, Septik abortuslar. Ektopik gebelik, görülme sıklığı son yıllarda artmakta olup, maternal mortalite ve morbiditenin ilk trimesterde en önemli nedeni olmaya devam etmekte ve ana ölümlerinin \%10-15'ini oluşturmaktadır (Tosun vd., 2007:37; Kızılkaya, 2017:510).

Gestasyonel Trafoblastik Hastalık (GDM)'ın insidansı coğrafik bölgelere göre değişiklik göstermektedir. Kuzey Amerika ve Avrupa ülkelerinde daha az rastlanırken Türkiye'de, insidans1 0.3-16/1000 gebelik, 1-24.5/1000 doğum olarak tespit edilmiştir. GDM, mol hidatiform (bölgesel ya da bütünsel), invaziv mol (koryoadenoma) ve koryokarsinoma olarak üç tipte görülür. Mol insidansı, ABD'de 1/2000 iken, Güney Asya ve Uzak Doğu'da 1/200 oranına düşebilmektedir (Sevil ve Ertem, 2016:184). Gestasyonel trofoblastik hastalık oluşumunda etkili olduğu pek çok araştırııı tarafından bildirilen predispozan faktörler: menarş, parite, ilk gebelik yaşı, geçirilmiş mol gebelik öyküsü, önceki gebelikler arasındaki süre, genetik faktörler, malnütrisyon, viral enfeksiyonlar, sosyoekonomik düzey ve Asya kökenli olmaktır. Yirmi yaş altı ve 40 yaş üzerindeki gebeliklerde insidansı artmaktadır (Çetin vd., 2004:18).

Gebelikte bulantı kusma oldukça yaygın görülen gebenin yalnızca fiziksel ve psikolojik iyilik halini değil, aynı zamanda sosyal işlevselliğinin de tüm yönleriyle etkilemektedir (Power et al., 2009:189). İlk trimesterde olan gebelerin \%80-90'1 bulantı kusma semptomunu yaşamakta, şikâyetler genellikle gebeliğin dördüncü haftası başlamakta, 16. haftasında kendiliğinden düzelmektedir. (Yanıkkerem vd., 2012). Hipermezis Gravidarum, gebeliklerin \%0,5-2.0'inde görülür, inatçı bulantıkusma, dehidratasyon, elektrolit dengesizliği, ketonüri ve kilo kaybı ile karaktarizedir. Erken gebelikte hastaneye başvurmanın en yaygın nedenidir. (Vikanes et al., 2010:1) En çok 7-12. haftalarda \%1 oranında görülür. (Kızılkaya, 2017:512). Gebelikte bulantı kusmanın nedeni bilinmemekle birlikte human koryonik gonodotrop hormonunun (HCG) artması, yüksek östrojen düzeyi, B6 vitaminin yetersizliği ve psikolojik stresin neden olduğu düşünülmektedir. (Yanıkkerem vd.. 2012; Kızılkaya, 2017:512).

\section{Düşük Tedavisinde Tamamlayııı Tıp Etkili Olabilir mi?}

İlk Trimester düşüklerinde ileri yaş gebelikler ve tütün kullanımı risk faktörü olarak görünmesine rağmen düşüklerin \%50-70'inin kromozomal anomalilerden kaynaklandığı bilinmektedir. Tamamlayıcı ve alternatif tı (CAM) terapileri, düşük riski altındaki kadınlara destekleyici bakımı vermede etkili olabilmektedir (Betts et al., 2012:1). Düşük tedavisinde başvurulan CAM terapileriyle ilgili yapılan bazı çalışmalar Tablo 1'de verilmiştir. Düşük yapmaktan kaçınmak için birçok girişim uygulanmıştır, ancak yatak istirahati, düşük tehditi ve önceki düşük geçmişleri için en sık verilen rehabilitasyondur. Buna 
rağmen yatak istirahatinin değerinin kanıtı azdır. Çok az çalışmada, yatak istirahatinin etkinliği değerlendirilmiştir (Qureshi, 2009:35).

Olguların çoğunda düşüğün etiyolojisi, aşırı aktivite ile ilgili olmadığından, yatak istirahatinin spontan düşük için etkili bir strateji olabileceği pek düşünülmez. Bir cohrane araştırmasında 84 kadından oluşan iki çalışma yapılmıştır. Sonuçlar karşılaştırıldığında yatak istirahatli olmayan gruba karşı yatak istirahatli grupta düşük riskinde istatiksel olarak anlamlı bir fark saptanmadı. Evdeki yatak istirahatide ve hastanedeki yatak istirahatide düşüğü önleme de önemli bir fark göstermedi. Ayrıca yatak istirahati grubundaki kadınlarda, yatak istirahati olmadan human koryonik gonadotropin (Hcg) tedavisi grubuna göre bir düşük riski yüksekti. (Aleman et al., 2005). Bir başka retrospektif çalışmada gebeliğin ilk yarısında vajinal kanama nedeniyle ultrason muayenesi için başvuran 230 kadında subkoryonik bir hematom bulunduğunu tespit ettiler. Tüm hastalara evinde yatak istirahati önerildi. 200 gebe bu öneriye uyarken, 30 gebe her zamanki yaşam biçimine devam etmiştir. Sonuç olarak yatak istirahatine uyan kadınların spontan düşük oranı daha düşük çıkmıştır. (BenHaroush et al., 2003:422). Düşük tehditinden dolayı hastaneye yatırılan 226 kadının dahil edildiği retrospektif analize göre; yatak istirahatine katılan 146 hastanın \%84'ünün gebeliğini 20. haftanın sonuna kadar sürdürdüğünü, buna karşın yatak istirahati yapılmayan 80 hastanın \%80'inin sürdüğü gösterilmiştir ve bu sonuçlar, yatak istirahatinin düşük tehditi prognozunu iyileştirmediğini göstermektedir. (Giobbe et al., 2001:337).

Çin bitkisel ilaçları Asya ülkelerinde yüzyıllarca yaygın bir şekilde kullanılmış ve son yıllarda Batı ilaçlarına popüler bir alternatif haline gelmiştir. Çin ilaçları yaygın soğuk algınlığı, bel ağrısı, düşük, erken doğum, düşük fetal ağırlık, büyüme kısıtlaması, plasenta previa, preeklampsi ve diğer obstetrik problemli hamile kadınlar için yaygın kullanılmaktadır. Tüm çalışmalar arasında hamilelik boyunca klinik çin tıbbı uygulamalarından en yaygını düşüktür (\%43.8). (Li et al., 2014:106). Birçok çalışma, düşük yapmayı engelleyebileceklerini göstermek için başvurmaktadır. Bununla birlikte, düşük tehlikesi için Çin bitkisel ilaçlarının etkililiğinin sistematik bir değerlendirmesi yapılmamıştır. Tümü Çin'den gelen 5100 katılımcının katıldığ 44 randomize çalışma arasında, herhangi bir araştırma, kontrol müdahalesi olarak plasebo veya yatak istirahatini kullanmadı. Yirmi denemede Shou Tai Pill'in ortak bir reçetesi (dört bitkiden oluşuyor diğer 24 deneme diğer formül kullanılmıştır. Beş deneme, gebeliğin ve doğumun 28. haftasına kadar 550 kadını izledi ve Çin bitkisel ve Batı ilaçlarının, yalnızca Batıdaki ilaçlardan daha fazla tehdit altındaki düşük tedavisinde etkili olduğunu gösterdi. Kaçınılmaz düşük yapılmasını önlemek için kombine tedavi, Batı ilaçlarına göre daha etkiliydi, böylece gebelik devam etti (Li et al., 2012:91).

Avusturya ve Yeni Zelanda'da 370 katılımcının olduğu bir çalışmada bir dizi Geleneksel Çin Tıbbı (TCM) yöntemi kullanılmıştır. En yaygın, akupunktur \%92.6, bunu takiben oksijen \%67.6, Çin bitkisel ilaçları \%67.0, TCM yaşam tarzı önerileri \%62.8 ve TCM diyet öneri \%51.2’'dir. Diğer yöntemler (\%9.1) qigong dahil, ısı lambaları, gevşeme teknoloji ve Batı bitkisel takviyelerinin kullanıldı̆̆ı belirtilmiştir (Betts et al., 2014:20).

Doğurganlık araştırmasında, akupunkturun erken gebelikte spesifik yararlı etkileri teşvik edebileceğini düşündüren düşük oranlarda yararlı hormonal (serum kortizol ve prolaktin) yanıtları gösterir. Düşük tehlikesi ile başvuran kadınlar için mevcut tıbbi seçeneklerin olmaması, akupunktur gibi CAM terapilerinin sağlanmasının olası tedavi yararları incelenmelidir. (Betts et al., 2012). Akupunkturun düşük tehditlerinde etkili bir tedavi olduğuna dair henüz inandırıcı bir kanıt bulunmamaktadır. Çin'den gelen klinik çalışmalar, batı medikal ortamlarında akupunktur ile ilgili klinik araştırmalardan farklı ölçütleri karşılamak için geliştirilmiştir. Akupunkturun etkili bir tedavisi olduğu sıklıkla kabul görürken, halk sağlığı sistemi içinde kullanılmaları gerektiğini göstermek için denemeler yapılabilir. Akupunktur tedavisine fizyolojik cevapları incelemek amacıyla küçük prospektif bir çalışmada kadınlar, IVF tedavisi görürken hormonal değişiklikler açısından test edildi. Akupunktur alan 34 kadın, tek başına IVF tedavisi alan 33 kadına kıyasla, serum kortizol ve prolaktin düzeylerinde (IVF gebelik oranlarını etkilediği düşünülen stres hormonları) önemli değişiklikler olduğunu gösterdi. Buna ek olarak, bu çalışma, akupunktur tedavisi gören kadınlar arasında düşük riski oranlarında belirgin bir düşüş bulmuştur. Bunu doğrulamak için daha fazla çalışma yapmak gerekirken, akupunkturun erken gebelikte, tehdit altındaki düşüklerle birlikte olan kadınlara avantajlı

olabilecek yararlı hormonal yanıtları teşvik etme potansiyeli vardır. (Magarelli vd., 2009 :1870) Rastgele kontrollü bir deneme ve yarı yapılandırılmış görüşmeler içeren karışık yöntemler çalışmasında vajinal kanaması olan 6-11 haftalarda gebeliği olan 40 katılımcı ele alınmıştır. Akupunktur tedavisinin sonunda kadınlarda kanama, kramp ve bel ağrısı gibi düşük tehlikesi şikâyetleri ile istatistiksel olarak anlamlı bir azalma vardı. Ayrıca kadınların hastanede tıbbi olarak destek ve alınan tavsiyelerden memnun olmadığını ortaya koyulmuştur. Katılımcıların temaları olarak: "yapabileceklerinden başka bir şeyleri olmadığını”, faydaları hissetmek ve "zamanı yönetmek" için akupunktura başvurdukları söylenmiştir (Betts et al., 2016:298). 
Tablo 1.Düşük Tedavisinde Başvurulan Tamamlayıcı Tıp Uygulamalarıyla İlgili Yapılan Çalışmalar

\begin{tabular}{|c|c|c|c|c|c|}
\hline $\begin{array}{c}\text { Çalışma } \\
\text { yılı }\end{array}$ & $\begin{array}{l}\text { Çalışma } \\
\text { Kimliği }\end{array}$ & Çalışma Grubu & $\begin{array}{l}\text { Çalışma } \\
\text { Konusu }\end{array}$ & Müdahale & Sonuç \\
\hline 2005 & $\begin{array}{l}\text { Aleman ve } \\
\text { arkadaşı }\end{array}$ & $\begin{array}{l}\text { Vajinal kanaması olan } \\
\text { gebe kadınlar, } \\
\text { gestasyonel yaşı sekiz } \\
\text { haftanın altında olan } \\
\text { ultrason ile onaylanmış } \\
\text { canlı embriyolu } 84 \\
\text { gebe }\end{array}$ & $\begin{array}{c}\text { Düşüğü } \\
\text { önlemek için } \\
\text { normal } \\
\text { aktiviteye } \\
\text { karşı yatak } \\
\text { istirahatinin } \\
\text { etkisi ve hcg } \\
\text { ile yatak isti- } \\
\text { rahati kar- } \\
\text { şılaştırması }\end{array}$ & $\begin{array}{l}\text { Çalışmalardan biri rastgele seçilmiş } 61 \\
\text { kişiden oluşuyordu (vajinal kanaması } \\
\text { olan sekiz haftanın altında ultrason ile } \\
\text { onaylanmış gebe kadınlar). Bunlar } \\
\text { kendi içlerinde üç gruba ayrıldı: Yatak } \\
\text { istirahati (cinsel aktivite olmadan), } \\
\text { plasebo (yatak istirahati olmadan ve } \\
\text { plasebo sıvı ampuller), human karyonik } \\
\text { gonadotropin tedavisi (parenteral } \\
10.000 \text { IU başlangıç dozu 12. haftaya } \\
\text { kadar) alanlar. Diğer grupta } 23 \text { kadın } \\
\text { dâhil edilme kriterlerini karşıladı ve } \\
\text { kabul etti. Üç gruba ayrıldı; evde yatak } \\
\text { istirahati, hasta-nede yatış ve normal } \\
\text { aktivite Takip eden aylarda ayda bir } \\
\text { ziyaret (ultrason ve kan takibi). } 16 . \\
\text { haftaya kadar rutin yapıldı. }\end{array}$ & $\begin{array}{c}\text { Yatak istirahatli } \\
\text { olmayan gruba kaşı } \\
\text { yatak istirahatli grupta } \\
\text { düşük riskin de } \\
\text { istatiksel olarak anlamlı } \\
\text { bir fark saptanmadı. } \\
\text { Yatak istirahati } \\
\text { grubundaki kadınlarda, } \\
\text { yatak istirahati olmadan } \\
\text { human koryonik } \\
\text { gonadotropin (Hcg) } \\
\text { tedavisi grubuna göre } \\
\text { daha yüksek bir düşük } \\
\text { riski vardı. }\end{array}$ \\
\hline 2003 & $\begin{array}{l}\text { Ben-Haroush } \\
\text { ve } \\
\text { arkadaşları }\end{array}$ & $\begin{array}{c}\text { Subkoryonik } \\
\text { hematomlu } 230 \text { kadın }\end{array}$ & $\begin{array}{l}\text { Yatak isti- } \\
\text { rahati ve } \\
\text { spontan düşük }\end{array}$ & $\begin{array}{l}\text { Tüm hastalara evinde yatak istirahati } \\
\text { önerildi. } 200 \text { gebe bu öneriye uyarken, } \\
30 \text { gebe her zamanki yaşam biçimine } \\
\text { devam etmiştir. Kanama durana kadar, } \\
\text { subkoronik hematom kaybolana kadar } \\
\text { veya kürtaj ortaya çıkana kadar, } \\
\text { hepsine yedi günlük aralıklarla } \\
\text { tekrarlanan sonogramlar uygulandı }\end{array}$ & $\begin{array}{l}\text { Yatak istirahatine uyan } \\
\text { kadınların spontan } \\
\text { düşük oranı daha } \\
\text { düşük çıkmıştır. }\end{array}$ \\
\hline 2016 & $\begin{array}{l}\text { Betts D. Ve } \\
\text { arkadaşları }\end{array}$ & $\begin{array}{c}\text { Yeni Zelandanın } \\
\text { Wellington ve Hutt } \\
\text { Vadisi bölgelerinde } \\
\text { yaşayan 6-11 hflık } 40 \\
\text { gebe }\end{array}$ & $\begin{array}{l}\text { Akupunktur ve } \\
\text { düşük semp- } \\
\text { tomları } \\
\text { arasındaki } \\
\text { ilişki }\end{array}$ & $\begin{array}{l}\text { Tüm kadınlar müdahalenin ilk haftası } \\
\text { boyunca iki ziyaret aldı ve bunları } 12 \\
\text { haftalık gebelik haftalarına kadar } \\
\text { haftalık ziyaret izledi. Tedaviler bir } \\
\text { akupunktur kliniğinde veya kadınların ev } \\
\text { ortamında talep edildiyse verildi }\end{array}$ & $\begin{array}{c}\text { Akupunktur alan } \\
\text { kadınlarda kanama, } \\
\text { kramp ve bel ağrısı gibi } \\
\text { tehdit altındaki düşük } \\
\text { şikâyetleri ile } \\
\text { istatistiksel ola-rak } \\
\text { anlamlı bir azalma } \\
\text { vardı }\end{array}$ \\
\hline 2001 & $\begin{array}{l}\text { Giobbe ve } \\
\text { arkadaşları }\end{array}$ & $\begin{array}{l}\text { Romadaki Policlinico } \\
\text { Umberto Kadın } \\
\text { Hastalıkları ve Doğum } \\
\text { Kliniğinde gebelikle ilgili } \\
\text { nedenlerle hastaneye } \\
\text { kaldııılmış daha önce } \\
\text { düşük tehditi ile yatmış } \\
\text { olan } 226 \text { hasta }\end{array}$ & $\begin{array}{l}\text { Yatak istirahati } \\
\text { ve düşük } \\
\text { tehlikesi } \\
\text { arasındaki } \\
\text { ilişki }\end{array}$ & $\begin{array}{c}\text { Ekim } 1998 \text { ile Haziran } 1999 \text { tarihleri } \\
\text { arasındaki hastaneden yatan kadınların } \\
\text { takibi }\end{array}$ & $\begin{array}{l}\text { Yatak istirahatinin } \\
\text { düşük tehditi } \\
\text { prognozunu } \\
\text { iyileştirmediğini } \\
\text { göstermektedir. }\end{array}$ \\
\hline 2012 & $\begin{array}{c}\text { Li LI. Ve } \\
\text { arkadaşları }\end{array}$ & 550 gebe & $\begin{array}{l}\text { Çin bitkisel ve } \\
\text { Batı ilaçlarının } \\
\text { düşük tehditi } \\
\text { için } \\
\text { karşılaştırılma } \\
\text { sı }\end{array}$ & $\begin{array}{c}\text { Yirmi denemede Shou Tai Pill'in ortak } \\
\text { bir reçetesi (dört bitkiden oluşuyor: çin } \\
\text { yem tohumları (Cuscuta Chinensis), } \\
\text { taxillus dalla-rı, donkey hide glue (Colla } \\
\text { corii asini), himalaya teasel kökü (Radix } \\
\text { Dipsaci)) temel bir formül olarak } \\
\text { kullanııırken diğer } 24 \text { deneme diğer } \\
\text { formül kullanılış̧ı̧ı. Batı ilaçları } \\
\text { salbutamol ve magnezyum sülfat gibi } \\
\text { tokolitik ilaçlar, insan koryonik } \\
\text { gonadotropin veya progesteron ile } \\
\text { hormonal destek ve E vitamini ve folik } \\
\text { asit içeren destekleyici takviyeleri } \\
\text { içeriyordu. Beş deneme, gebeliğin ve } \\
\text { doğumun 28. haftasına kadar } 550 \\
\text { kadını izledi } \\
\end{array}$ & $\begin{array}{l}\text { Çinli bitkisel ve Batı } \\
\text { ilaçlarının, yalnızca } \\
\text { Batıdaki ilaçlardan } \\
\text { daha fazla düşük tehditi } \\
\text { te-davisinde etkili } \\
\text { olduğunu gösterdi }\end{array}$ \\
\hline
\end{tabular}

Hiperemezis Gravidarumda Tamamlayıcı Tıp Uygulamalarının Bakım Sürecine Etkisi

Günümüzde gebeliğin erken dönemlerinde görülen bulantı ve kusma semptomlarının giderilmesinde tamamlayıcı tıp uygulamaları kullanımı yaygınlaşmaktadır. Bunun nedeni ilaçların olumsuz etkilerine karşı duyulan endişedir (Matthews et al., 2015:1). Gebelikte tamamlayıcı tıp uygulamaları ve bitkisel 
ürün kullanımı kültürel ve bölgesel farklılıklara göre değişmektedir. Türkiyedeki kadınların \%47,3 ‘ünün gebelik sırasında en az bir bitkisel ürün kullanmakta olduğu ve yarısından fazlasının da bitkisel ürün kullanımına herhangi bir öneri almadan başladığı saptanmıştır (Kıssal vd., 2017:54-60). Başvurulan bu uygulamalar, belirsiz maternal ve fetal güvenlik sonuçları nedeniyle araştırılmışlardır. Bulantı kusma tedavisinde başvurulan tamamlayıcı tıp uygulamalarıyla ilgili yapılan bazı çalışmalara Tablo 2'de yer verilmiştir.

Zencefil, gebelerin mide bulantısı ve kusma tedavisinde başvurdukları nonfarmakolojik yöntemlerden en çok bilinenidir. Zencefilin kullanımı, kullanım dozu ve etkinliğine dair çelişkili açıklamalar mevcuttur. Mohammadbeigi ve arkadaşlarının (2011:817) yaptıkları bir çalışmada zencefil, metoklopramid ilacı ve plasebonun gebelikte karşılaşılan bulantı kusma üzerine etkisini araştırmışlardır. Çalışma sonucuna göre zencefil ve metoklopramid ilacının semptomların azaltılmasında etkili olabileceği belirtilmiștir. Birbirleriyle kıyaslandıklarında ise metoklopramid ilacının zencefile göre daha etkili olduğu saptanmıştır. Ancak bu fark istatistiksel olarak anlamlı bulunmamıştır. Basirat ve arkadaşları da (2009:51) 65 gebe üzerinde zencefilli bisküvilerin bulantı ve kusmayı nasıl etkilediğine dair bir çalışma yapmışlardır. Sonuç olarak zencefilli bisküvilerin bulantı şiddeti üzerine etkisinin kusmaya göre daha fazla olduğu belirtilmiştir. Ozgoli ve arkadaşları (2009:15(3):243-6) ise 67 gebede yaptıkları vaka kontrol çalışmasında zencefil kapsülleri ve plasebo etkinliğini karşılaştırmışlardır. Buna göre zencefil kapsülleri semptomların giderilmesinde etkili bir yöntem olarak kabul edilmiştir. Yine Viljoen ve arkadaşlarının (2014) 1278 gebe üzerinde yaptı̆̆ sistematik bir incelemede ise zencefilin plaseboya göre etkisi karşılaştırılmıştır. Bu incelemeye göre zencefil, mide bulantısı semptomlarını azaltmada yararlı bulunmuştur. Fakat zencefilin kusma ataklarını önemli derecede etkilemediği ve yan etkiler açısından önemli bir risk oluşturmadığı da belirtilmiştir. Saberi ve arkadaşları (2014) ise 106 gebede yaptıkları randomize plasebo kontrollü bir çalş̧mada zencefilin hafif-orta şiddette mide bulantısı üzerinde etkili olduğunu tanımlamışlardır. Firouzbakht ve arkadaşlarınca (2014:289) 120 gebeyle yapılan randomize ve çift-kör bir klinik araştırmada ise zencefilin gebelik bulantısını ve kusma semptomlarını azaltmada B6 vitamini kadar etkili olduğu saptanmıştır. Zencefilin, potansiyel yararları olduğu kadar potansiyel zararlarının da olabileceği unutulmamalıdır. Nedir bu durumlar? Koo ve arkadaşları yaptıkları bir araştırmada zencefilin aspirine benzer bir mekanizmayla trombosit agregasyonunu engellediğini belirtmişlerdir. Bu durum kanamaya yol açabilir. İlk trimesterde bu kanamanın gerçekleşmesi anne ve fetüs üzerinde zararlı etkilere yol açabilir (Koo, 2001: 387). Benzer olarak Marx ve arkadaşları (2015:1) ise zencefilin trombosit agregasyonu ve koagülasyonuna etkisinin bakıldığı sistematik bir inceleme yapmışlardır. Bu inceleme, sekiz klinik ve iki gözlemsel çalışmayı içermektedir. Sekiz klinik çalışmanın dördünde zencefilin trombosit agregasyonunu azalttı̆̆g, geri kalan dördünde ise herhangi bir etki bildirilmemiştir. Sonuç olarak zencefilin trombosit agregasyonu ve koagülasyonunu etkilediğine dair sunulan kanıtlar şüphelidir. Bu ikilemin kesin olarak çözülmesi için daha fazla çalışma yapılması gerekmektedir. Bununla birlikte Norveç'te 68.522 kadından oluşan geniş bir kohortta ise doğuştan malformasyonlar ve seçilmiş gebelik sonuçları açısından gebelik sırasındaki zencefil kullanım güvenliği sorgulanmıştır. Araştırmada kadınların 1.020 si $(\% 1.5)$ gebelik sırasında zencefil kullandıklarını bildirmişlerdir. Heitmann ve arkadaşlarına (2014:269) göre gebelik sırasında zencefil kullanımı konjenital malformasyon riski ile ilişkili değildir. Bütün bunlara dayanarak zencefil doğru kişiye, doğru zamanda, doğru dozda, doğru frekansta ve doğru uygulama rotasıyla önerilmelidir (Tiran, 2012:22). Hatta Finlandiya Gıda Güvenliği Otoritesi Evira'nın yaptığı gibi şu andaki potansiyel riskleri de içerecek bir biçimde bilinen gıda takviyeleri ve içecekler tablolaştırılmalıdır. Riskli görülen gıda takviyeleri kullanımında yol açacağı sorun ile birlikte "Tavsiye edilmiyor" gibi bir uyarı etiketi taşımalıdır.

Gebelerin erken dönemlerinde başvurdukları diğer bir tamamlayıcı tıp yöntemi ise vitaminlerdir. Bu dönemde kullanılan vitaminlerden birisi de tiamindir. Wegrzyniak ve arkadaşlarına göre B1 vitamini (Tiamin) uzun süreli kusmaları olan gebelerde rutin bir destek haline gelmelidir (Wegrzyniak, 2012:78). $\mathrm{Bu}$ dönemde kullanılan diğer bir vitamin ise B6 vitaminidir (Piridoksin). Shrim ve arkadaşlarınca (2006:749) günde 3 kere $10-25 \mathrm{mg}$ doz aralı̆̆ında kullanımının semptomları azalttı̆̆ ve hiperemezis gravidarumdan korunmada plasebodan üstün olduğu bildirilmiştir. Günlük doz, $200 \mathrm{mg}$ 'a kadar yan etki görülmeden arttırılabilir (Einarson, 2007:2109). Gebelerdeki bulantı ve kusma tedavisi ile ilgili yapılan randomize bir çalışmada B6 vitamininin zencefile göre daha etkili bir yöntem olduğunu belirtilmiştir (Ensiyeh ve Sakineh, 2009:53). Matthews ve arkadaşlarının (2015:1) yaptığı ve 4041 gebenin katıldığ 28 randomize çalışmada bulantı kusmaya yönelik alternatif tedavi yöntemleri karşılaştırılmıştır. Buna göre B6 vitamini hafif ve orta şiddetteki bulantı tedavisinde etkili olduğu fakat kusma tedavisinde etkili olmadığını bildiren çalışmalar mevcuttur. Yine de kullanımını destekleyen çalışmalar yetersizdir.

Gebelikte kullanılan tamamlayıcı tıp uygulamaları arasında limon yağı inhalasyonu da yer alır. Erick 'in yaptığı bir araştırmaya göre, kadınların \%40'ı bulantı ve kusmayı gidermek için limon kokusu kullanılmıştır ve bunların \%26,5'i semptomlarını kontrol etmede etkili bir yol olduğunu bildirmiştir 
(Erick, 2001:30). Kia ve arkadaşları (2013:1) tarafindan yapılan çift kör randomize kontrollü bir klinik çalışmada limon esansiyel yağının gebelikte karşlaşılan bulantı ve kusma üzerindeki etkisi araştırılmıștır. Çalışma 100 gebenin kontrol ve müdahale gruplarını olușturduğu dört günü değerlendirmiştir. İki grupta da ikinci ve dördüncü günlerde bulantı ve kusma puan ortalamaları arasında istatistiksel olarak anlamlı farklılıklar olduğu görülmüştür. Müdahale grubundaki ikinci ve dördüncü günlerde bulantı ve kusma skorları, kontrol grubuna göre anlamlı derecede düşük bulunmuş̧ur. Bununla birlikte fark birinci ve üçüncü günlerde anlamlı değildir. Bir diğer uygulama olan nane yağı ise aşırı kullanımı uterin kanamayla iliş̧kilendirilmiştir. Fleming (2009:186), nane yağını organogenez sırasında kontrendike ve gebelik sırasında kullanımını güvensiz kabul etmektedir. Pasha ve arkadaşları (2012:727) 60 gebede yaptığı çift kör randomize kontrollü bir çalışmada nane yağının bulantı kusma üzerindeki etkisini incelemişlerdir. Sonuç olarak bulantı ve kusma üzerine etkisinin olmadığı saptanmıştır. Literatürlede rastladığımız diğer bir uygulamada papatya kullanımıdır. Conover'e (2003:237) göre olası menstruasyon ve düşüğü uyarıcı etkileri nedeniyle gebelik sırasında kullanılmamalıdır.

Akupunktur noktalarının yakılan moksa otunun (Artemisia Vulgaris-Pelin) 1sısının etkisiyle uyarılması olarak tanımlanan ısı terapi (moxibustion) yöntemi son dönemlerde adını duyduğumuz tamamlayıcı tıp uygulamaları arasında yer alır. Moksa purosu olarak ta adlandırılan moksanın yerleștirildiği blok, cildin yaklaşık 2-3 cm üzerinde tutulur. Heuvel ve arkadaşları tarafindan yapılan sistematik bir tarama sonucu farklı uyarıcı tekniklerle beraber kullanımının bulantı ve kusmayı azaltmasına rağmen semptomları azalttı̆ğına dair bir sonuca varılamamıştır (Heuvel et al.,2016:1). Gebeliğin erken döneminde başvurulan tamamlayıcı tıp uygulamalarından birisi de masaj terapidir. Yapılan çalışmalar yeterli olmamakla birlikte genelde dokunsal masajın psikolojik rahatlatma yönü kullanılır. Agren ve arkadaşı hastanede yatan 10 gebede şiddetli bulantı kusma ile dokunsal masaj deneyimlerini tanımlaması üzerine bir çalışma yapmışlardır. Yapılan bu çalışmaya göre dokunsal masajın bulantı ve kusmaya dolaylı yoldan etki ettiğgi fakat bir genelleme yapılamadığ saptanmıştır. Dokunsal masajın uzun vadede etkilerinin araştırılabilmesi için sistematik bir incelemeye ihtiyaç olduğu belirtilmiştir (Agren and Berg, 2006:169). Tamamlayıcı tıp uygulamaları içerinde yer alan hipnozda gebelerde erken dönemde başvurulan yöntemler arasında yer almaktadır. Tıbbi hipnoz iyi belgelenmiş bir tedavi yöntemi olarak kabul edilir. $\mathrm{Bu}$ tedavi yöntemi Simon ve arkadaşlarının yaptı̆̆ bir çalışmada maternal ve fetal sağlık açısından tehlike oluşturmadığı gibi ilaç tedavisiyle kıyaslatıldığında kısa sürede sonuç alınabildiği vurgulanmıştır (Simon, 1999:248).

Akupunktur, vücudun belirli noktalarının iğneyle uyarılması şeklinde tanımlanır. Birçok çeşidi bulunmaktadir (Heuvel,2016:1). Bunlardan birisi kozmetik akupunkturdur. Gebelikte kontrendike kabul edilir, uygulanılmaz (Kaplan, 2016:16). Neri ve arkadaşlarının (2005: 471) 88 gebe üzerinde yaptıkları bir çalışmada bulantı kusmada akupunkturla beraber akupressür etkinliğini metoklopramid infüzyonuyla beraber B12 vitamin tedavisi etkinliğini karşılaştırmış̧ır. Bu çalışma sonucuna göre akupunktur diğerlerine göre daha etkili bir yöntem kabul edilmiştir. Bütün bunlara dayanılarak akupunktur kullanımıyla ilgili çelişkili sonuçlar olduğunu varsayabiliriz. Gebelik erken dönemindeki bulantı ve kusmanın tedavisinde başvurulan tamamlayıcı tıp uygulamaları içerinde akupressür de yer alır. Akupunktur noktalarına basınç uygulanarak uyarılması işlemi olarak tanımlanır. Girişimsel değildir (Helmreich,2006:412). Antiemetik tedaviler için PC6 (NeiGuan) ve KID21 noktaları kullanılır. KID21 noktası, altı CUN (Kişinin başparmağının boğumda parmağın enine yakın olduğu geleneksel Çin ölçü birimi) Göbeği ve orta çizginin her iki yanındaki 0.5 CUN'u iki simetrik noktadır (Rad et al., 2012:697). PC6 noktası, bilek kırışığının üç cm üstünde kolaylıkla palpe edilen iki tendon arasında volar tarafinda bulunur (King and Murphy, 2009:430). Gürkan ve Arslan'ın (2008:225) yaptıkları bir çalı̧̧mada akupressürün gebelerdeki bulantı kusma semptomlarına etkisini incelemişlerdir. Sonuç olarak akupressür gebelik sırasındaki mide bulantısı kusma semptomlarını azaltmada, semptom kontrolünde ve hafifletmesinde etkili olabileceği saptanmıştır (Gürkan ve Arslan, 2006:225). Yine Saberi ve arkadaşlarının (2013:854) yaptığı başka bir çalışmada ise gebelikte bulantı kusma tedavisinde zencefil ve akupressür etkisi karşılaştırılmıştır. Bu çalışmaya göre de gebelerde hafif ve orta şiddette bulantı ve kusmayı gidermek için zencefil akupressürden daha etkili bulunmuştur. Heuvel ve arkadaşları (2016:1) ise farklı akustimulasyon tekniklerinin etkinliklerini incelemişlerdir. Faydalı etkilerine dair kanttlar bulunmuştur. Fakat etkili bir yöntem demek için henüz erken olduğunun altı çizilmiştir. Gebelik başvurulan tamamlayıcı tıp uygulamalarını içerisinde sosyal desteğede yer verebiliriz. Karataş ve arkadaşının (2012:47) yaptığı bir çalışmada gebelikte karşılaşılan bulantı kusmayla gebelere sağlanan sosyal destek arasındaki ilişkiyi incelemiştir. Fakat ikisi arasında anlamlı bir fark bulanamamıştır. Daha fazla çalışmanın yapılması gerekmektedir. 
Tablo 2. Bulantı Kusma Tedavisinde Başvurulan Tamamlayıcı Tıp Uygulamalarıyla İlgili Yapılan Çalışmalar

\begin{tabular}{|c|c|c|c|c|c|c|c|c|}
\hline $\begin{array}{c}\text { Çalışma } \\
\text { yılı }\end{array}$ & $\begin{array}{l}\text { Çalışma } \\
\text { Kimliği }\end{array}$ & $\begin{array}{l}\text { Çalışma } \\
\text { Grubu }\end{array}$ & Çalışma Konusu & \multicolumn{3}{|c|}{ Müdahale } & Plasebo & Sonuç \\
\hline 2009 & $\begin{array}{l}\text { Basirat ve } \\
\text { arkadaşları }\end{array}$ & 65 gebe & $\begin{array}{l}\text { Erken gebelikte } \\
\text { zencefilli bisküvinin } \\
\text { bulantı ve kusma } \\
\text { üzerindeki etkisinin } \\
\text { incelenmesi. }\end{array}$ & \multicolumn{3}{|c|}{$\begin{array}{c}\text { 35(32+3) gebe Zencefilli } \\
\text { bisküviler (500 mg günde beş } \\
\text { defa = } 2500 \mathrm{mg} / \text { gün) (üç gebe } \\
\text { bisküvinin tadını beğenmedikleri } \\
\text { için çıkarıldı) }\end{array}$} & $\begin{array}{c}30 \text { gebe } \\
\text { belirtilmemiştir. }\end{array}$ & $\begin{array}{c}\text { Zencefilli bisküviler, } \\
\text { bulantı şiddetine ( } p \\
=0.01) \text { ve bir } \\
\text { dereceye kadar } \\
\text { kusmaya }(p=0.24) \\
\text { göre önemli } \\
\text { derecede daha } \\
\text { fazla rahatlama } \\
\text { sağlamıştır. }\end{array}$ \\
\hline 2009 & $\begin{array}{c}\text { Ozgoli ve } \\
\text { arkadaşları }\end{array}$ & $\begin{array}{l}67 \text { gebede } \\
4 \text { gün }\end{array}$ & $\begin{array}{l}\text { Zencefil kap- } \\
\text { süllerinin bulantı ve } \\
\text { kusma üzerinde } \\
\text { etkisinin incelenmesi. }\end{array}$ & \multicolumn{3}{|c|}{$\begin{array}{c}32 \text { gebe Zencefil toz kapsülleri } \\
\text { (günde dört kez } 250 \text { mg = } 1000 \\
\text { mg / gün) }\end{array}$} & $\begin{array}{c}\text { 35gebe Kapsüller } \\
\text { (laktoz) (250 mg } 4 \\
\text { x / d } 1000 \mathrm{mg} \mathrm{/} \\
\text { gün) }\end{array}$ & $\begin{array}{l}\text { Sonuçlar zencefilin } \\
\text { NVP semptomlarını } \\
\text { düzeltmede } \\
\text { plaseboya göre } \\
\text { anlamlı derecede } \\
\text { daha etkili olduğunu } \\
\text { göstermiştir (p } \\
<0.05) \text {. }\end{array}$ \\
\hline 2009 & $\begin{array}{l}\text { Saberi ve } \\
\text { arkadaşları }\end{array}$ & $\begin{array}{c}106 \text { gebe } \\
16 \text { hafta } \\
\text { öncesi (ilk } \\
\text { üç gün } \\
\text { beklenildi } \\
\text { son dörtgün } \\
\text { inceledi }\end{array}$ & $\begin{array}{l}\text { Zencefilin bulantı ve } \\
\text { kusmadaki gerileme } \\
\text { üzerine etkisinin } \\
\text { incelenmesi }\end{array}$ & $\begin{array}{c}\text { (Müda-hale) } \\
37 \text { gebe } \\
\text { Zencefil } \\
\text { kapsülleri } \\
\text { (günde üç kez } \\
250 \text { mg=750 } \\
\text { mg/gün) }\end{array}$ & \multicolumn{2}{|c|}{$\begin{array}{l}\text { (Kontrol) } 33 \\
\text { gebe } \\
\text { Belirtilmemiş }\end{array}$} & $\begin{array}{l}\text { (Plasebo) } 36 \text { gebe } \\
\text { Laktoz kapsülleri } \\
\text { (Günde üç kez } 250 \\
\text { mg=750 mg/gün) }\end{array}$ & $\begin{array}{l}\text { Hafif-orta şiddette } \\
\text { bulantı ve kusmayı } \\
\text { zaltmada etkilidir. } \\
\text { Bu çalışma hafif } \\
\text { orta şiddette mide } \\
\text { bulantısı ve kusma } \\
\text { üzerinde } \\
\text { yapıldığından } \\
\text { sonuçlar şiddetli } \\
\text { bulantı ve kusmayı } \\
\text { kapsamaz. }\end{array}$ \\
\hline 2010 & $\begin{array}{l}\text { Firouz- } \\
\text { bakht ve } \\
\text { arkadaşları }\end{array}$ & $\begin{array}{c}120- \\
23=97 \text { gebe } \\
18-35 \text { yaş } \\
20 \text { hf öncesi } \\
\text { dört gün }\end{array}$ & $\begin{array}{l}\text { Gebelikte bulantı ve } \\
\text { kusmanın } \\
\text { giderilmesinde zen- } \\
\text { cefil ile vitamin } \\
\text { B6'nın } \\
\text { karşılaştırılması }\end{array}$ & $\begin{array}{l}\text { (Zencefil) } 24 \\
\text { gebe Zencefil } \\
\text { kapsülü: } \\
\text { Zintoma, } 250 \\
\text { mg) }\end{array}$ & \multicolumn{2}{|c|}{$\begin{array}{l}\text { (B6 Vita-mini) } \\
35 \text { gebe } B 6 \\
\text { vitamini: } 40 \mathrm{mg} \\
\text { oral }\end{array}$} & $\begin{array}{c}\text { (Plasebo) } 38 \text { gebe } \\
\text { Şeker:40 mg }\end{array}$ & $\begin{array}{l}\text { Zencefil, gebelik } \\
\text { bulantısını ve } \\
\text { kusmayı azaltmada } \\
\text { B6 kadar etkilidir. }\end{array}$ \\
\hline 2011 & $\begin{array}{l}\text { Mohamadb } \\
\text { eigi ve } \\
\text { arkadaşları }\end{array}$ & $\begin{array}{l}102 \text { gebe } \\
\text { beş gün }\end{array}$ & $\begin{array}{c}\text { Zencefil ve } \\
\text { metoklopramidinin } \\
\text { gebelik bulantılarının } \\
\text { tedavisine etkisinin } \\
\text { araştı-rılması. }\end{array}$ & $\begin{array}{c}34 \text { gebe } \\
\text { Zencefil özü } \\
\text { kap sülleri } \\
\text { (200 mg } 3 \text { x / } \\
\text { gün = } 600 \mathrm{mg} \\
\text { / gün) }\end{array}$ & \multicolumn{2}{|c|}{$\begin{array}{c}34 \text { gebe } \\
\text { Metoklopramid } \\
\text { kap sülleri (10 } \\
\text { mg } 3 \text { x / gün = } \\
30 \text { mg / gün) }\end{array}$} & $\begin{array}{l}34 \text { gebe Un kapsül } \\
200 \text { mg } 3 \text { x / gün = } \\
600 \text { mg / gün) }\end{array}$ & $\begin{array}{c}\text { Zencefil, gebelik } \\
\text { sırasında bulantı ve } \\
\text { kusmayı azaltmada } \\
\text { me-toklopramidden } \\
\text { daha az etkili } \\
\text { bulunmuştur. Ancak } \\
\text { fark istatistisel } \\
\text { olarak anlamlı } \\
\text { değildir }(p=0.509) \text {. }\end{array}$ \\
\hline 2013 & $\begin{array}{l}\text { Yavari Kia } \\
\text { ve } \\
\text { arkadaşları }\end{array}$ & $\begin{array}{c}\text { Sağlık } \\
\text { ocağına } \\
\text { gönderilen } \\
\text { bulantı ve } \\
\text { kusması } \\
\text { olan } 100 \\
\text { gebe (dört } \\
\text { gün) }\end{array}$ & $\begin{array}{l}\text { Limon inha-lasyonu } \\
\text { aroma terapisinin } \\
\text { gebelikte bulantı ve } \\
\text { kusma üzerine } \\
\text { etkisinin incelen- } \\
\text { mesi }\end{array}$ & \multicolumn{4}{|c|}{$\begin{array}{l}10 \text { ml Limon yağı } \\
\text { (müdahale) Mide } \\
\text { bulantısı hissettik-lerinde } \\
\text { verilen pamuklara iki } \\
\text { damla solüsyon damlatılıp } \\
\text { üç cm uzakla-rında tutup } \\
\text { üç kez derin nefes } \\
\text { almaları söylenmiştir. } \\
\text { Bulantıları devam etmeleri } \\
\text { halinde beş dakika sonra } \\
\text { bunları tekrarlamaları } \\
\text { söylenmiştir. }\end{array}$} & $\begin{array}{l}\text { İki gruptada 2. ve } 4 . \\
\text { günlerde istatistiksel } \\
\text { olarak anlamlı bir } \\
\text { fark bulunamamıştır. } \\
\text { Müdahale } \\
\text { grubundaki 2. ve } 4 \text {. } \\
\text { günde ise bu-lantı } \\
\text { ve kusma skorları } \\
\text { kontrol grubuna } \\
\text { göre anlamlı } \\
\text { derecede düşüktür. } \\
\text { Fakat 1. ve 3. } \\
\text { günlerde bu fark } \\
\text { anlamlı değildir. }\end{array}$ \\
\hline
\end{tabular}




\begin{tabular}{cccc}
\hline 2000- & Agren ve & 23-38 yaş & Hastanede yatan \\
2002 & arkadaşı & arasındaki & kadınların şiddetli \\
& & $7-13$ & bulantı ve kusma ile \\
& & haftalık 10 & dokunsal masaj \\
& gebe & deneyim-lerini \\
& & tanımla-ması
\end{tabular}

\begin{tabular}{|c|c|c|c|}
\hline 2005 & $\begin{array}{c}\text { Neri ve } \\
\text { arkadaşları }\end{array}$ & 88 gebe & $\begin{array}{c}\text { Akupunktur, } \\
\text { akupressür } \\
\text { seanslarının ile } \\
\text { metoklopramid / } \\
\text { vitamin B12 teda- } \\
\text { visinin etkinliğini } \\
\text { karşılaş-tırmaktır. }\end{array}$ \\
\hline
\end{tabular}

Sessiz bir odada en az 10'ar saat arayla üç kez dokunsal masaj yapıldı. Masaj, rahatlatıcı müzik eşliğinde yavaş ve yumuşak bir şekilde verildi. Hiçbir sözlü iletişim kullanılmadı. Her masaj yaklaşık $60 \mathrm{dk}$ sürdü. Son masajdan sonra bir odada her bir kadınla görüşüldü. Görüşmeler 12- 25 dk. arasında sürdü. Ve iki soru soruldu.

Grubun kusma ve bulantısına dolaylı yoldan etki etmiştir.

Fakat kişi sayısı az olduğu için genelleme yapılamayabilir. Kısa süreli etkisi

incelenmiştir. Uzun vadede etkisi için sistematik bir

araştırma yapılması gerekmektedir.

43 gebe Akupunktur + P6 $\mathbf{3 8}$ gebe Metok-lopramid Her iki tedavinin de akupressür Akupunktur infüzyo-nu+Vitamin B12 HG semptomlarında seansları geleneksel Çin kompleksi Metok-lopramid aynı etkiyi gösteren tıbbı kri-terlerine göre infüzyonu (60 dk boyunca ilaçlarla haftada iki kez iki hafta $20 \mathrm{mg} / 500 \mathrm{ml}$ salin) karşılaştırılmıştır. boyunca hastanede haftada iki kez iki hafta Sadece aku-punktur gerçekleştirildi. süreyle hastaneye ile önemli ölçüde Akupressür 6-8 saat / gün kaldırıldı. B12 vitamini iyileşmiştir. süreyle uygulandı. kompleksi (30 mg / gün) ile oral yoldan ilave edildi.

\begin{tabular}{|c|c|c|c|c|c|c|c|}
\hline 2011 & $\begin{array}{c}\text { Rad ve } \\
\text { arkadaşları }\end{array}$ & $\begin{array}{l}80 \text { gebe } \\
\text { Dört gün }\end{array}$ & $\begin{array}{l}\text { Akupressür (KID21 } \\
\text { nok-tasında) } \\
\text { gebeliğin bulantı ve } \\
\text { kusma üzerine olan } \\
\text { etkisini belirlemektir. }\end{array}$ & $\begin{array}{c}\text { Ardışık dört gün üst üste } \\
\text { günde } 20 \text { dakika KID21 } \\
\text { noktasına akupressür } \\
\text { baskısı }\end{array}$ & \multicolumn{2}{|c|}{$\begin{array}{l}\text { Aynı şekilde sahte KID21 } \\
\text { noktasına akupressür } \\
\text { baskısı }\end{array}$} & $\begin{array}{l}\text { KID21 noktasındaki } \\
\text { akupressür, } \\
\text { gebelikte bulantı ve } \\
\text { kusmayı a-zaltmada } \\
\text { plasebodan daha } \\
\text { etkilidir. Dördüncü } \\
\text { günde mide } \\
\text { bulantısı ve kusma } \\
\text { şiddeti farklılık } \\
\text { gösterdi }(\mathrm{P}<0.001) \text {. }\end{array}$ \\
\hline 2009 & $\begin{array}{l}\text { Saberi ve } \\
\text { arkadaşları }\end{array}$ & $\begin{array}{c}159 \text { gebe } \\
\text { yedigün (İlk } \\
\text { üç gün bir } \\
\text { şey } \\
\text { yapılmadı } \\
\text { sonraki dört } \\
\text { gün } \\
\text { müdahale } \\
\text { yapıldı) }\end{array}$ & $\begin{array}{l}\text { Gebelikte bulantı ve } \\
\text { kusma tedavisinde } \\
\text { zencefil ve } \\
\text { akupressür etkinliğini } \\
\text { karşılaştırmaktır. } \\
\text { (Sea bandı, Nei- } \\
\text { Guan noktasında } \\
\text { baskı yapmak için } \\
\text { kullanılan düğmeli bir } \\
\text { el bileği bandıdır.) }\end{array}$ & $\begin{array}{c}\text { Akupressür Akupressür } \\
\text { grubundaki her bir kadına, } \\
\text { bir grup sea bandı (Sea- } \\
\text { Band, Birleşik Krallık, Ltd. } \\
\text { Leicester, İngiltere) verildi } \\
\text { ve dört gün süreyle sürekli } \\
\text { kullanmaya (yalnızca } \\
\text { banyo yaparken çıkarma) } \\
\text { çalıştılar. 7. güne kadar } \\
\text { her iki eldeki uygun yere } \\
\text { koyun. }\end{array}$ & $\begin{array}{c}\text { Zencefil } \\
\text { Zencefil } \\
\text { grubundaki } \\
\text { her bir kadın, } \\
\text { dört gün (dört } \\
\text { ile yedi gün } \\
\text { boyunca) ve } \\
\text { her gün üç } \\
\text { kapsül için } 12 \\
\text { zencefibir } \\
\text { kapsül }\end{array}$ & $\begin{array}{c}\text { Kontrol } \\
\text { Müdahale } \\
\text { yapılmadı }\end{array}$ & $\begin{array}{c}\text { Semptomatik } \\
\text { gebelerde } 16 \\
\text { haftanın altında } \\
\text { gebelik haftasın-da } \\
\text { hafif ve orta şiddette } \\
\text { bulantı ve kusmayı } \\
\text { gidermek için } \\
\text { zencefil } \\
\text { akupressürden } \\
\text { daha etkilidir. }\end{array}$ \\
\hline 2010 & $\begin{array}{c}\text { Karataş ve } \\
\text { arkadaşı }\end{array}$ & $\begin{array}{c}450 \text { gebe } \\
20-39 \text { yaş } \\
20-24 \text { hf }\end{array}$ & $\begin{array}{c}\text { Gebelikte bulantı } \\
\text { kusmayla sosyal } \\
\text { destek arasındaki } \\
\text { ilişkinin incelenmesi }\end{array}$ & $\begin{array}{r}3 \text { form kullanılmıştır.1.for } \\
\text { formu 2.form: Geber } \\
\text { değerlendirme formu; } 3 . \text { fo } \\
\text { sosyal des }\end{array}$ & $\begin{array}{l}\text { n: Gebelerin ta } \\
\text { in bulantı kusm } \\
\text { m: Çok boyutlı } \\
\text { tek ölçeği }\end{array}$ & $\begin{array}{l}\text { tıcı bilgi } \\
\text { sını } \\
\text { algılanan }\end{array}$ & $\begin{array}{l}\text { Gebelikteki bulantı } \\
\text { kusma ile sosyal } \\
\text { destek arasında } \\
\text { anlamlı bir fark } \\
\text { bulunamamıştır. }\end{array}$ \\
\hline 2011 & $\begin{array}{c}\text { Pasha ve } \\
\text { arkadaşları }\end{array}$ & 60 gebe & $\begin{array}{l}\text { Nane yağının bulantı } \\
\text { ve kusma üzerindeki } \\
\text { etkisinin in- } \\
\text { celenmesi }\end{array}$ & $\begin{array}{c}\text { Bir bardak su içerisine dört } \\
\text { nane yağı damlatılarak dört } \\
\text { üst üste yataklarının yakını } \\
\text { zemine yerleştirildi. }\end{array}$ & $\begin{array}{rr}\text { amla } & \text { Bir barc } \\
\text { yece } & \text { dört ge } \\
\text { daki } & \text { yata } \\
& \text { yakının } \\
& \text { yerl }\end{array}$ & $\begin{array}{l}\text { k tuzlu su } \\
\text { üst üste } \\
\text { arının } \\
\text { ki zemine } \\
\text { tirildi. }\end{array}$ & $\begin{array}{l}\text { Nane esansiyel } \\
\text { yağının, gebelikte } \\
\text { bulantı ve kusma } \\
\text { üzerine etkisi } \\
\text { olmadığını sap- } \\
\text { tanmıştır. }\end{array}$ \\
\hline
\end{tabular}

\section{Tamamlayıcı Tıbbın Hemşirelikteki Yeri}

Günümüzde birçok hastalıklarının tedavisinde ve semptomlarının hafifletilmesinde ya da giderilmesinde tamamlayıcı ve alternatif tıp (TAT) yöntemleri kullanmaktadır. TAT tedavilerinin birçoğunun etkinliğine dair çok sınırlı kanıtlar olmasına, bu alanda yapılan çalışmaların metodolojilerinin zayıf olmasına ve sağlık bakım maliyetlerini arttırmasına karşın, özellikle son yıllarda kullanımı Avrupa, Amerika ve Avustralya'da artış göstermiştir (Tokem 2006:189). Hemşirelik uygulamalarının ve tamamlayıcı tedavilerin temel felsefesi aynıdır. Her ikisinin benzer yönleri, bireye holistik açıdan yaklaşmaları, tedavi sırasında destekleyici rolde olmaları, sağlı̆ıı yükseltilmesine ve hastanın aktif rolde olmasına odaklanmalarıdır (Breen 2003:268).

Sonuç ve Öneriler

Günümüzde ilaçların olumsuz etkilerine karşı duyulan endişeden dolayı bitkisel ürün ve tamamlayııı tıp uygulamaları kullanımı yaygınlaşmakta olduğu görülmüştür. Literatür tarandığında ektopik gebelik ve 
gestasyonel trofoblastik hastalık adına çalışmalar bulunamamıştır. Düşüğün önlenmesinde kısıtlı sayıda çalışma mevcuttur. Bu dönemde en çok rastladığımız çalışma bulantı ve kusmayla ilgili yapılmıştır. Düşüğün önlenmesinde birçok tamamlayıcı tıp yönteminin kullanıldığı görülmüştür. Bunlar arasında en sık kullanılanı yatak istirahatıdır. Buna karşı bu yöntemlerin etkinliği konusunda bilimsel kanıtlar yetersizdir ve daha sistematik bir şekilde değerlendirmeye ihtiyaç duyulmaktadır.

Bulantı ve kusmanın giderilmesi için başvurduğumuz yöntemlerden en sık kullanılanı zencefildir. Yapılan çalı̧̧ma sonuçlarına göre zencefilin bulantı ve kusma semptomlarının giderilmesinde kesin olmamakla beraber etkili bir yöntem olduğu kabul edilir. Bahsedilen olumsuz etkileri nedeniyle riskli görülen gıda takviyeleri arasında yer alabileceği unutulmamalıdır. Bu gibi durumları da göz önüne alarak gebelik döneminde kullanımını veya fazla kullanımını risk oluşturabilecek içecek ve yiyecekler tablolaştırılmalıdır. Ve bu gıda takviyeleri kullanımında yol açacağı risk ile birlikte "Gebelikte tavsiye edilmiyor." gibi bir uyarı ibaresi taşımalıdır. B1 vitamininin kusmada, B6 vitamininin semptomların azaltılmasında etkili olduğunu söyleyen çalışmalar mevcuttur fakat bunların kullanımını destekleyen çalışmalar yetersiz, kanıtlar sınırlıdır. Nane yağının semptomlarda etkili olmadığı saptanmış ayrıca gebelikte kullanımı güvensiz kabul edilmektedir. Daha güncel ve kanıt içeren çalı̧̧maların yapılması gerekmektedir. Limon yağı inhalasyonu bulantı ve kusma semptomlarını gidermede etkili bulunmuştur. Papatyanın menstruasyon ve düşü̆gü uyarı etkilerinden dolayı kullanımı önerilmemektedir. Yapılan çalışmalar eski ve kanıtlar yetersizdir. Daha fazla çalışmanın yapılması gereken bir alandır. Akupunktur kullanımıyla ilgili çelişkili sonuçlar bulunmaktadır. Daha kapsamlı çalışmaların yapılması gerekmektedir. Isı terapinin, semptomlara etkisi görülmemiştir. Masaj terapinin ve sosyal desteğin etkinliği konusunda yeterli kanıt yoktur. Güncel, kapsamlı ve sistematik çalışmalara ihtiyaç duyulmaktadır.

Tamamlayıcı tıbbın birçoğunun etkinliğine dair çok sınırlı kanıtlar olmasına karşın özellikle son yıllarda kullanımı yaygınlaşmıştır. Türkiye'de tamamlayıcı tıp uygulamalarına yasal bir boyut kazandırmak için "Geleneksel ve Tamamlayıcı Tıp Uygulamaları Yönetmeliği” hazırlanmıştır. Fakat bu yönetmelik kapsamında hemşire ve ebelere uygulama yetkisi verilmemiştir. Aslında, tamamlayıcı terapilerin, hemşirelik girişimi olarak uygulanabileceği görülmektedir. Bu nedenlerden dolayı tamamlayıcı terapiler ve kullanımına ilişkin bilgiler, hemşirelik müfredatına konmalı, ayrıca hizmet içi eğitim programları kapsamında tamamlayıcı terapiler konusunda hemşirelerin bilgi birikimleri güncellenmelidir. Hemşirelerin bağımsız roller kapsamında uygulama yetkisine sahip olmaları için yönetmelik yasal prosedürler ve bu prosedürlerdeki hemşirelerin rol ve yetkileri açısından tekrar gözden geçirilmesi gerekmektedir.

\section{KAYNAKLAR}

AGREN, A., BERG, M. (2006). Tactile Massage And Severe Nausea And Vomiting During Pregnancy-Women's Experiences. Scand J Caring Sci; 20(2):169-176 doi:10.1111/j.14716712.2006.00394.x

ALEMAN, A., ALTHABE, F., BELIZÁN, J.M., BERGEL, E., (2005). Bed Rest During Pregnancy For Preventing Miscarriage. Cochrane Database of Systematic Reviews, Issue 2.Art. doi:10.1002/14651858.CD003576.pub2

BASIRAT, Z., MOGHADAMNIA A., KASHIFARD, M., SHARIFI-RAZAVI, A., (2009). The Effect of Ginger Biscuit on Nausea and Vomiting in Early Pregnancy. Acta Medica Iranica, 47(1): $51-56$

BEN-HAROUSH, A., YOGEV, Y., MASHIACH, R., MEIZNER, I., (2003). Pregnancy Outcome Of Threatened Abortion With Subchorionic Hematoma: Possible Benefit Of Bed-Rest? Isr Med Assoc Jun, 5(6):422-424

BETTS, D., SMITH, CA., DAHLEN, H.G., (2012). Acupuncture As A Therapeutic Treatment Option For Threatened Miscarriage. Complementary and Alternative Medicine, 12:20 doi:10.1186/1472$6882-12-20$ 
BETTS, D., SMITH, CA, DAHLEN, HG. (2014). "Well I'm Safe Because..."acupuncturists managing conflicting treatment recommendations when treating threatened miscarriage: a mixedmethods study. J Altern Complement Med, 20(11):838-45 doi: 10.1089/acm.2014.0139

BETTS, D., SMITH, C.A., DAHLEN, H.G., (2016). Does Acupuncture Have A Role In The Treatment Of Threatened Miscarriage? Findings from a feasibility randomised trial and semistructured participant interviews. BMC Pregnancy and Childbirth, 16(298) doi: 10.1186/s12884016-1092-8

BREEN, K.J., (2003). Ethical Issues In The Use Of Complementary Medicines. Climacteric, 6(4): 268-272

CONOVER, E.A., (2003). Herbal Agents And Over The Counter Medications In Pregnancy. Best Pract Res Clin Endocrinol Metab, 17(2):237-251

ÇETIN, M., BALTA, Ö., DURAN, B., GÜVENAL, T. YANAR, O., (2004). Kliniğimize Başvuran Mol Gebelik Olgularının Retrospektif İncelenmesi, C. Ü. Tıp Fakültesi Dergisi, 26 (1):18 - 22

ÇEV, YILDIRIM., M., OKAR İ., DALÇIK H., (2002). Klinik önleri ile İnsan Embriyolojisi (Çev). 6.baskı. İstanbul, Türkiye: Nobel Tıp Kitabevleri. ss. 34

EINARSON, A., MALTEPE, C., BOSKOVIC, R., KOREN, G., (2007). Treatment Of Nausea And Vomiting In Pregnancy: An Updated Algorithm. Can Fam Physician, 53(12): 2109-2111

ENSIYEH, J., SAKINEH, M. A., (2009). Comparing Ginger And Vitamin B6 For The Treatment Of Nausea And Vomiting In Pregnancy: A Randomised Controlled Trial. Midwifery, 25(6): 53-649

ERICK, M., (2001). Morning Sickness Impact Study. Midwifery Today, 59:30-32

FINNISH FOOD SAFETY AUTHORITY EVIRA, (2016). General instructions on safe use of food stuffs.

https://www.evira.fi/globalassets/elintarvikkeet/tietoaelintarvikkeista/elintarvikevaarat/elintarvik keiden-kayton rajoitukset/16.11.evira_taulukko1_eng.pdf, Erişim Tarihi:24.04.2017

FIROUZBAKHT M., NIKPOUR M., JAMALI B., OMIDVAR S., (2014). Comparison Of Ginger With Vitamin B6 In Relieving Nausea And Vomiting During Pregnancy, Ayu, In international Quertelly journal of research in ayurveda, 35(3): 289-293

FLEMING, T., (2009). PDR for herbal medicines. Thomson HealthCare Inc. 4th ed., USA: UCLA, pp. 186

GIOBBE, M., FAZZIO, M., BONI, T., (2001). Current Role Of Bed-Rest In Threatened Abortion. Minerva Ginecol, 53:337-40

GÜRKAN, A., BİLGE, A., (2006). Alternatif terapiler ve psikiyatri hemşireliği. Ege Üniversitesi Hemşirelik Yüksek Okulu Dergisi, 22 (1): 225-232

HEITMANN, K., NORDENG, H., HOLST, L., (2014). Safety Of Ginger Use In Pregnancy: Results From A Large population-based cohort study. Eur J Clin Pharmacol, 69:269-277. doi: $10.1007 / \mathrm{s} 00228-012-1331-5$

HEUVEL, E.V., GOOSSENS, M., VANDERHAEGEN, H., SUN H.X. AND BUNTINX, F., (2016). Effect Of Acustimulation On Nausea And Vomiting And On Hyperemesis In Pregnancy: A Systematic Review Of Western And Chinese Literatüre, BMC Complementary and Alternative Medicine, 16(13):1-18 
HELMREICH, R.J., SHIAO, S.Y., DUNE, L.S., (2006). Meta-Analysis Of Acustimulation Effects on Nausea and Vomiting in Pregnant Women. September, 2(5):412-421

KAPLAN A., (2014). Kozmetik Akupunktur. Ankara Akupunktur ve Tamamlayıcı Tip Dergisi, $1(6): 16-22$

KARATAŞ, T., METE, S., (2012). Gebelikte Bulantı Kusma Sorunu Yaşama Durumu ile Sosyal Destek Arasındaki İlişskinin İncelenmesi, Dokuz Eylül Üniversitesi Hemşirelik Yüksekokulu Elektronik Dergisi, 5(2):47-52, Erişim Tarihi:11.04.2017

KIA, Y.P., SAFAJOU, F., SHAHNAZI, M., NAZEMIYEH, H., (2014). The Effect Of Lemon Inhalation Aromatherapy On Nausea And Vomiting Of Pregnancy: A Double-Blinded, Randomized, Controlled Clinical Trial. Iran Red Crescent Med J., 16(3):1-6

KING, T.L., MURPHY, P.A., (2009). Evidence-Based Approaches to Managing Nausea and Vomiting in Early Pregnancy: Journal of Midwifery \& Women's Health.Nov., 54(6):430-444

KISSAL A., GÜNER, Ü.Ç., ERTÜRK D., (2017). Use Of Herbal Product Among Pregnant Women In Turkey. Complementary Therapies in Medicine, 30:54-60

KOO, K.L., AMMIT, A.J., TRAN, V.H., DUKE C.C, ROUFOGALIS B.D., (2001). Gingerols And Related Analogues Inhibit Arachidonic Acid-Induced Human Platelet Serotonin Release And Aggregation. Thromb Res., 103:387-397

KOREN, G., (2006). Pregnancy Outcome Following Use Of Large Doses Of Vitamin B6 In The First Trimester. J Obstet Gynaecol., 26(8): 749-751

LI, L., DOU, L., LEUNG, P.C., WANG, C.C., (2012). Chinese Herbal Medicines For Threatened Miscarriage. The Cochrane Library. New York, USA: John Wileyand Sons., 5(1).DOI: 10.1002/14651858.CD008510.pub2

LI, L., LEUNG, P.C., WANG, C.C., (2014). The Efficacy and Safety of Chinese Medicines for Threatened Miscarriage, in Miscarriage: causes, symptoms and prevention. Ed: Pannel VM. NOVA Publisher, Hong Kong.4: 106-147

MAGARELli, P.C., CRIDENNDA, D.K., COHEN, M. (2009). Changes In Serum Cortisol And Prolactin Associated With Acupuncture During Controlled Ovarian Hyperstimulation In Women Under Going In Vitro Fertilization-Embryo Transfer Treatment. Fertil Steril, 92:1870-1879

MARX, W., MCKAVANAGH, D., MCCARTHY, A, BIRD, R., RIED, K., CHAN A, ISENRING L. (2015). The Effect Of Ginger (Zingiber officinale) On Platelet Aggregation: A Systematic Literature Review. PloS One, 1-13

MATTHEWS, A., DOWSWELl T., HAAS, D.M., DOYlE M., OMATHUNA, D.P., (2015). Interventions For Nausea And Vomiting In Early Pregnancy. Cochrane Database of Systematic Reviews. Europe PMC Funders Group Author Manuscript, (9):1-68

MOHAMMADBEIGI R., SHAHGEIBI S., SOUFIZADEH N., REZAIIE M., FARHADIFAR F., (2011). Comparing The Effects Of Ginger And Metoclopramide On The Treatment Of Pregnancy Nausea. Pak J Biol Sci., 14(16):817-20

NERI, I., ALlAIS, G., SCHIAPPARELli, P., BLASI, I., BENEDETTO, C., FACCHINETTI, F., (2005). Acupuncture Versus Pharmacological Approach To Reduce Hyperemesis Gravidarum Discomfort. Minerva Ginecol, 57(4):471-475 
OZGOLI, G., GOLI, M., SIMBAR, M., (2009). Effects Of Ginger Capsules On Pregnancy, Nausea, And Vomiting. J Altern Complement Med., 15(3):243-246. doi: 10.1089/acm.2008.0406

PASHA, H., BEHMANESH, F., MOHSENZADEH, F., HAJAHMADI, M., MOGHADAMNIA, A.A., (2012). Study Of The Effect Of Mint Oil On Nausea And Vomiting During Pregnancy. Iran Red Crescent Med J., 14(11):727-730. doi: 10.5812/ircmj.3477

POWER, Z., CAMPELL, M., KILCOYNE, P., KITCHHENER, H., WATERMAN, H., (2009). The Hyperemesis Impact of Symptoms Questionnaire: Development and Validation Of A Clinical Tool. International Journal of Nursing Studies, 54 (2): 189-196

RAD, M. N., MINOOR LAMYIAN, M., HESHMAT, R., JAAFARABADİ M.A., AND YAZDANI, S., (2012). A Randomized Clinical Trial of the Efficacy of KID21 Point (Youmen) Acupressure on Nausea and Vomiting of Pregnancy, Iran Red Crescent Med J., 14(11): 697-701

QURESHI, N.S. (2009). Treatment options for threatened miscarriage. Maturitas, 65:35-41

SABERI F., SADAT Z., ABEDZADEH-KALAHROUDI M., TAEBI M., (2013). Acupressure And Ginger to Relieve Nausea and Vomiting in Pregnancy: a Randomized Study: Iranian Red Crescent Medical Journal. September, 15(9):854-61

SABERI, F., SADAT, Z., ABEDZADEH-KALAHROUDI, M., (2014). Effect of Ginger on Relieving Nausea and Vomiting in Pregnancy: A Randomized, Placebo-Controlled Trial: Nursing and Midwifery Studies, 3(1):1-6

SEVİL, Ü., ERTEM, G., (2016). Perinatoloji ve Bakım, Ankara, Türkiye: Nobel Tıp Kitabevleri, ss. 184

SHRIM, A., BOSKOVIC, R., MALTEPE, C., NAVIOS, Y., GARCIABOURNISSEN, F., (2006). Pregnancy Outcome Following Use Of Large Doses Of Vitamin B6 In The First Trimester. J Obstet Gynaecol, 26(8): 749-751

SIMON, E.P., SCHWARTZ, J., (1999). Medical Hypnosis for Hyperemesis Gravidarum. 249BIRTH, 26(4):248-254

T.C. MİLLİ EĞİTİM BAKANLIĞI (2012). Hemşirelik, Gebelik Ve Fetüs Fizyolojisi, Ankara, Erişim Tarihi:11.04.2017

TIRAN, D., (2012). Ginger To Reduce Nausea And Vomiting During Pregnancy: Evidence Of Effectiveness Is Not The Same As Proof Of Safety. Complement Ther Clin Pract, 18:22-25 doi: 10.1016/j.ctcp. 2011.08 .007

TOKEM, Y., (2006). Astımlı hastalarda tamamlayıcı ve alternatif tedavi kullanımı. Tüberküloz ve Toraks Dergisi, 54(2):189-196

TOSUN, M., KAYA, A., KÖKÇÜ, A., MALATYALIOĞLU E., ÇETINKKAYA, M.B., ALPER, T., (2007). Ektopik Gebelik Olgularında Tedavi Yaklaşımları, O.M.Ü. Tıp Dergisi, 24(2): 37-42

VIKANES, A., SKJAERVEN, R., GRIJIOBOVSKI, A. M., GUNNES, N., VANGEN, S., MAGNUS, P., (2010). Recurrence of Hyperemesis Gravidarum Across Generations: Population Based Cohort Study. British Medical Journal, 340(291):1-5

VILJOEN E., VISSER J., KOEN N., MUSEKIWA A., (2014). A Systematic Review And MetaAnalysis Of The Effect And Safety Of Ginger In The Treatment Of Pregnancy-Associated Nausea And Vomiting. Nutr J, 19:13-20 doi: 10.1186/1475-2891-13-20 
VERMA, S.K., BORDIA A., (2001). Ginger, Fat And Fibrinolysis. Indian J Med Sci., 55:83-86

WEGRZYNIAK, L. J., REPKE, J.T., URAL, S. H., (2012). Treatment Of Hyperemesis Gravidarum. Rev Obstet Gynecol. 5(2): 78-84

YANIKKEREM, E., ÇALIM, S.İ., GÖKER, A., KOLTAN, S.O., KOYUNCU, F.M., (2012). Hiperemezis Gravidarum'lu Gebelerin Hastalıkları Hakkında Düşünceleri Ve Gereksinimleri, Gümüşhane Üniversitesi Sağlık Bilimleri Dergisi, 1(4):269-283

\section{EXTENDED ABSTRACT}

Definition and Importance: Pregnancy is the event that begins with the union of male and female reproductive cells and ends with a birth when a new creature is born. The average gestationperiod for humankind is 40 weeks or 280 days (MEB, 2012). The 9-month gestation period is divided into 3-month periods, which is called trimester. From week 1 through week 12 is named 1 st trimester, from week 13 through week 28 is named 2nd trimester, from week 29 through week 40 is named 3rd trimester(Kızllkaya, 2017). Gestation period is an important term which physiological, psychological and social changes are experienced in women's life and it is necessary to adapt to these changes. (Karataş ve Mete, 2012). Many people see gestation as a natural event that results in a healthy new born world. However, in every pregnancy, risky situations may occur which may have negative consequences for fetus, mother or both (Kizllkaya, 2017) Among these risky cases, those seen in the first trimester are spontaneous abortion, ectopic pregnancy, gestational trophoblastic disease (GDM), hyperemesis gravidarum. Today, the use of herbal products and complementary medicine applications is becoming widespread against the health problems seen in the early period of pregnancy. The reason for that is the concerns about negative effect of drugs. Complementary medical practices in pregnancy and the use of herbal products vary according to cultural and regional differences. Aim: This review was carried out to investigate complementary medical practices in health problems experienced in first trimester pregnancies according to the literature and to examine the place of complementary medicine in nursing. Results: There were no studies on ectopic pregnancy and gestational trophoblastic disease when the literature was searched. It has been observed that most of your work was about nausea and vomiting seen in this period. However, it is observed that the results of these studies do not contain conclusive evidence. Bed rest, chinese herbal medicines, acupuncture have been used in the prevention of miscarriages. Among these, bed rest is the most frequently used. On the contrary, the scientific evidence on the effectiveness of these methods is inadequate and needs to be evaluated in a more systematic way. In hyperemesis gravidarum, it has been observed that many complementary medical methods such as ginger, vitamin B1, vitamin B6, lemon oil inhalation, mint oil, chamomile, moxibustion, tactile massage, hypnosis, acupuncture, acupressure and social support are used. Among these methods, ginger is the most commonly used. The efficacy of relieving the symptoms of nausea and vomiting of ginger in the study results was different. It was found to be effective on nausea and vomiting. But there is no certainty. It should be remembered that ginger may be among the food supplements that are considered risky due to the mentioned negative effects. Taking such situations into account, beverages and foods that are at risk during pregnancy or at risk of overuse should be tabulated. And it should carry a warning notice such as "It is not recommended during pregnancy" with the risk of using it in food supplements. There are studies that say that vitamin B1 is effective in vomiting and that vitamin B6 is effective in reducing symptoms, but the studies supporting their use are inadequate and the evidence is limited. Peppermint oil was found to be ineffective in symptoms and its use in pregnancy was considered unsafe. The work done is insufficient. More current and evidence-based studies are needed. Lemon oil inhalation has been found effective in relieving the symptoms of nausea and vomiting. Current work to be done to resolve the symptoms of nausea and vomiting can be evaluated in different aspects of the lemon outside the inhalation. Daisy is not recommended due to menstruation and low stimulation effect. The research done is old and the proof is insufficient. More research needs to be done about this field. There are contradictory results regarding the use of acupuncture. A field that needs to be investigated more thoroughly. There is insufficient evidence of the effectiveness of massage therapy and social support. Current, comprehensive and systematic studies are needed. Although there is very limited evidence of the effectiveness of some complementary medicine, its use in recent years has increased in Europe, America and Australia. As a result, it became a necessity for nurses to meet the health needs of the 
individual, the family and the community in order to take part in complementary therapies. "Regulation on Traditional and Complementary Medical Practices" has been prepared in order to give a legal dimension to complementary medicine applications in Turkey. Despite that within the scope of this regulation, no authority was given to nurses and midwives. In fact, complementary therapies can be implemented as nursing interventions when the literature is examined. For these reasons, information on complementary therapies and their use should be included in the nursing curriculum, as well as the nurses' knowledge of complementary therapies should be updated in the context of in-service training programs, the legal procedures in the US and Europe, Nurses need to be re-examined in terms of roles and authorities. 